\title{
Climate Change Adaptation and Mitigation Strategies in Lagos, Nigeria: Built Environment Professionals' Perspective
}

\author{
Adedotun O. Akinola, Akunnaya P. Opoko, Eziyi O. Ibem, Hilary I. Okagbue, Adedeji O. Afolabi
}

\begin{abstract}
In recent times, the need for concrete steps to be taken in the adaptation and mitigation of the effects of climate change has taken the centre stage in development discourse. However, there is a scarcity of empirical studies on the extent to which built environment professionals, especially in a developing country like Nigeria are aware of the various climate change mitigation and adaptation strategies. This study examined the level of awareness of climate change adaptation and mitigation strategies amongst built environment professionals in Lagos, Nigeria. The data were sourced through a cross-sectional survey of 71 respondents including, architects, builders, town planners, estate managers and quantity surveyors in the study area using an online questionnaire. The data were subjected to descriptive statistics and the result shows that the built environment professionals identified the main causes of climate change to include the use of fossil fuels in industrial production, automobiles, and generation of electricity. Also, the major effects of climate change were flooding and excessive heat, while the top three adaptation and mitigation strategies greening/planting trees, enforcement of building guidelines and the use of energy-efficient technologies. This study implies that the built environment professionals are very much aware of the existing climate change adaptation and mitigation strategies but there is an urgent need to internalize them in the production and management of the environment in Nigeria.
\end{abstract}

Keywords: Adaptation, Mitigation, Awareness, Built environment professionals, Climate change, statistics.

\section{INTRODUCTION}

The global rise in temperature, unusual rise in sea level, heat waves, shorter winter, distortion in rainfall patterns, glacier melts in Antarctica and incessant wildfires are some

Revised Manuscript Received on February 05, 2020.

* Correspondence Author

Adedotun O. Akinola, Department of Architecture, Covenant University, Ota, Nigeria. Email: adedotun.akinola@stu.cu.edu.ng

Akunnaya P. Opoko, Department of Architecture, Covenant University, Ota, Nigeria.

Eziyi O. Ibem, Department of Architecture, Covenant University, Ota, Nigeria.

Hilary I. Okagbue*, Department of Mathematics, Covenant University, Ota, Nigeria. Email: hilary.okagbue@covenantuniversity.edu.ng

Akunnaya P. Opoko, Department of Building Technology, Covenant University, Ota, Nigeria.

(C) The Authors. Published by Blue Eyes Intelligence Engineering and Sciences Publication (BEIESP). This is an open access article under the CC BY-NC-ND license (http://creativecommons.org/licenses/by-nc-nd/4.0/) of the manifestations of the climate change. Generally, it is widely believed that environmental pollution is the major risk factor of climate change and that these challenges have been exacerbated by rapid urbanisation, modernization and development.

Historically, the built environment in Nigeria is plagued with some problems that have to starve it of substantial development, automation and modernization [1]. The short supply of buildings [2], high demand for houses, land tenure and speculation, poverty and unaffordable houses [3-4] and overcrowding, corruption and violation of adequate procurement and construction best practices [5] are very critical issues. Added to these are low adoption of sustainable construction practices such as lean principles [6], poor environmental and housing quality [7], building collapse and high cost of building materials [8]. These issues have combined to present an enormous challenge of which the government and private sector are struggling to address.

In addition to the aforementioned challenges are the overbearing effects of climate change. The current realities are that innovative strategies are required in the design of environmentally friendly buildings and surrounding environments that can help mitigate the effects of climate change [9]. Mitigation and adaptation strategies can be innovative approaches to the design, construction and management of buildings. The efforts are not limited to buildings but also to the overall environmental management, planning of cities and initiation of environment resilience strategies that can help the environment withstand natural disasters [10-13]. Tackling climate change will help improve the quality of life of the populace by reducing noise and air pollution levels, proper drainage, and road construction management, efficient human and material waste disposal and smart transportation system. As Adetokunbo and Emeka [14] rightly observed, this can trigger positive economic growth and transformation of cities to environmentally friendly and resilient urban systems.

Construction of dams and canals has been identified as two of the earliest inventions to mitigate the effects of climate changes [15]. In Nigeria, many of the existing dams are operating at below capacity and the canals are in comatose or dilapidating state due to low maintenance culture. Besides, illegal houses have been constructed in areas designated for canals, thereby causing massive obstruction of a free flow of storm water Furthermore; massive urbanization in Nigeria has led to indiscriminate felling of trees and proliferation of illegal structures in reversed lands. Several studies have been carried out on the mitigation and adaptation strategies of climate change in Nigeria. 
For examples, [16] examined energy savings in housing through occupants' behaviour and recommended the incorporation of energy efficient strategies in buildings to reduce the effect of climate change.

In the same vein, [17] discussed the various asset adaptation strategies employed by the people living in the rural areas in developing their adaptive capacity and resilience to climate variability using the participatory climate change adaptation evaluation and a proposed modification of asset portfolios in reducing the climate impacts. Anake et al. [18] also estimated the potential of six common tree species growing at residential and industrial areas of Ota, Ogun State, southwest Nigeria and suggested the planting of bio-indicators and tolerant tree species, while [19] investigated thermodynamic impact on building in a poor urban setting in Lagos State and recommended thermodynamic consideration in architectural design.

Despite the insight gained from available studies, there is still yet a dearth of empirical evidence on built environment professionals' level of awareness of the mitigation and adaptation strategies for climate change in Nigeria. It is argued that obtaining expert' opinions on the mitigation and adaptation strategies for the effects of climate change in the built environment would engender the domestication of these strategies in the production and management of the built environment in Nigeria. For this purpose, the present study is on the built environment professional's awareness of climate change adaptation and mitigation strategies in Lagos, Nigeria. The specific objectives are to 1) investigate the causes of climate change as perceived by built environment professionals, 2) the adverse effects of climate change, 3) the extent of awareness and adoption of climate change adaptation and mitigation strategies by built environment professionals in the study area. The findings of this study are expected to inform policy and practice in the implementation of climate change adaptation and mitigation strategies in the study area. It is also considered an addition to the current discourse on climate change literature from the perspective of a developing country.

\section{LITERATURE REVIEW}

\section{A. Awareness of Climate Change}

According to [20], awareness can be described as one's ability to notice things or a state of being fully conscious of what one knows or what one has learned. Awareness of climate change in the built environment is a predictor of mitigation strategies and often regarded as the first step in the identification of climate vulnerability and adaptation procedures [21-22]. Adequate awareness of the effects of climate change on buildings and environment has led to the development of green buildings which is one of major components of urban greenery [23-24] and green economy [25]. Awareness is also responsible for the integration of climate change adaptation and mitigation strategies into government policy or sustainable development goals [26-27]. Sustainability in buildings means designing a building to withstand the effects of climate change and to ensure low energy consumption, indoor comfort [28-29], adequate ventilation and reduction of carbon emissions [30-32]. In addition, sustainability in this context can be described as mitigation strategies against greenhouse gas emissions [33], reduction of the effect of thermal radiation on buildings [34-36], as well as a reduction in the cost of buildings using cheaper and environmentally friendly building materials [37-38]. Sustainability will guarantee that the city is resilient against the onslaught of climate change [39], improving the overall health of the people [40], increase user satisfaction [41] and economic advancement [42]. In addition, cultural practices could be incorporated in the awareness programme to secure the cooperation of all the necessary stakeholders, especially in the developing countries [43-44].

The issue of promoting awareness of environmental issues has featured prominently in some previous works. For example, awareness of the adoption of models to curtail the adverse effects of climate change on the ecosystem has been proposed by [45]. Similarly, awareness of resilience and the needs to prepare the urban areas against natural disasters [46]. Such as increasing incidence of wildfires triggered by climate change [47], drought and acute water shortages [48-49], flooding and landslides [50-51] are well documented in research literature. It has however been observed that a high level of awareness has not always translated to faithful implementation of policies crafted to mitigate the effects of climate change on the built environment [52]. This was echoed in a paper that investigated the implementation of measures to prevent the dilapidation of heritage sites because of climate change [53]. In the same vein, bureaucratic bottlenecks have been identified as obstacles in coordinating climate change mitigating strategies [54]. Davies et al. [55] noted that concrete actions have not been taken to minimize the effect of pollution on the urban environment despite the high awareness of the dangers inherent in inaction.

The foregoing notwithstanding, it is known that awareness of environmental issue will increase the awareness level of individuals who are motivated to tackle emerging challenges in the environment [56]. Therefore, it is argued that awareness of climate change is an easy way to become an environmental steward and participate in creating a sustainable environment, which is why awareness has been regarded as playing a prominent role in the identification of climate vulnerability and adaptation procedures within a specific local environment.

\section{B. Causes and effects of climate change the built environment}

The built environment constitutes all buildings; manmade environments including blue and green space where human activities take place [57]. It is made up of land uses comprising buildings and grey (such as roads, parking spaces, etc.), blue (e.g. water bodies, rivers, canals, etc.) and green (urban parkland, gardens, woodland, green areas, etc.) infrastructure [58]. According to [59], the built environment as consisting of a network of the interlocking infrastructure of energy supply, sewage, telecommunications, transport, water and waste management. Therefore, Hossein et al. [60] have insisted that the built environment is a key player in promoting sustainable development, improving quality of life, comfort, security and health of people, among others; and that these goals can only be achieved under a sustainable environment.

Published By: 
It is on this premise that Babalola et al. [6] have argued that the built environment professionals are key players in environmental sustainability agenda because the roles they play in the design, planning, construction, maintenance of buildings and provision of quality urban infrastructure.

From the review of literature, it was found that temperature, sea-level rise, storm patterns, precipitation and other environmental conditions affect the management of buildings and infrastructure in the built environment [61]. In addition, cities are critical to the fight against climate change, however, cities and particularly those in the developing countries lack institutional, financial and technical capacities to adapt to the impacts of climate change [62]. Consequently, the need to formulate effective policies for the adaptation and mitigation of climate change has taken the centre stage in climate change discourse [62-65]. For instance, studies on the built environment professionals' awareness of climate change adaptation and mitigation strategies have been considered highly important in the formulation of policies and implementation of programmes for effective adaptation and mitigation of the effects of climate change locally and globally.

As earlier noted, climate change is the variation in weather elements over time, due to human activities or natural vulnerability [62]. Notably, climate change poses an enormous amount of threat to the built environment and particularly the construction sector [62] [66]. Urbanization in coastal areas continues to increase at an alarming rate despite the increasing risks of a changing climate. The effects can manifest as storm surges, hurricanes, cyclones and flooding [67]. Emissions of greenhouse gases, largely from energy production and consumption, agriculture and other ecological processes has been implicated as causes of climate change. The activities causing most greenhouse gas emissions are key drivers of global socioeconomic development [68]. It has also been observed that Africa is not a major driver but a victim of climate change [62]. According to [64], climate change is caused by uncontrolled human activities and natural processes. The author made it clear that some man-made factors like urbanization, transportation, land use, deforestation, and industrialization are contributory factors to the current wave of climate change globally. These man-made activities are responsible for the emission of greenhouse gases (GHGs) such as carbon dioxide (CO2), Nitrous Oxide (N2O), Methane (CH4), Ozone (O3) and Chlorofluorocarbons (CFCS) that have caused global warming, which has, in turn, resulted in climate change. However, the natural factors that have also been linked to climate change include solar radiation quality and quantity, the astronomical position of the earth among others.

In recent years, the rise in sea level, longer hours of heavy downpours, heat waves, erosion and other climate-related phenomena are already damaging buildings and infrastructure and these damages are projected to increase if climate change challenges are not addressed [61] [63]. Consequently, the challenges of climate change and their impacts on the built environment are increasing unabated. In addition to the several other impacts of climate change, a study by the UN Habitat [69] noted that flood and other climatic effects have a tremendous effect on the functionality of buildings. Several authors [63] [65] [70] have identified the effects of climate change to include flooding, heat waves/higher temperature, rising sea/ocean levels, longer/shorter raining season, increase in storm intensity, erosion (frequency and intensity), desertification, more frequent drought, well, stream and river drying up. Others are a proliferation of pests and diseases, landslide, crop yield reduction, and food scarcity. All these are known to have diverse effects on man in particular and the ecological system in general.

\section{Climate change adaptation and mitigation strategies}

Adaptation is regarded as the initiatives and measures used as strategies to reduce the vulnerability and the effects of natural and human factors against happenings. On the other hand, mitigation in this context, is the premeditated measures or implementation of relevant policy geared towards slowing down the rate of greenhouse gas emissions levels and enhance the sustainability of the environment [62].

The mitigation and adaptation strategies are too numerous to mention but there are some significant ones, especially in the developing countries. These include planting trees (green areas), enforcement of building guidelines, the use of energy-efficient technologies, public awareness on climate, demolishing structures obstructing drainage, avoiding development on flood prone lands, the use of resilient building materials, compliance with setbacks during property development and advancement of renewable energy [65]. Others are construction of dams for flood protection [15], construction of sea walls to protect low-lying coastal areas from rising sea levels, construction of drainage channels around houses, restriction of land reclamation activities, producing and using flood risk maps. There are also measures such as: raising the building level, reliance on weather forecast, building high walls to prevent floods, repair/replace damaged property, the use of local herbs and drugs to climate-related diseases, and consulting the rainmaker, Use of prayers/charms/incantations [63] [65]. In spite of the existence of these strategies in the literature, it is not clear how built environment professionals are aware and the extent to which they have adopted them. The current study attempts to bridge this gap.

\section{RESULTS AND DISCUSSION}

Lagos State was selected for this study due to the influence of high human activities involved in construction, manufacturing and other sectors affecting climate change. Lagos State has a population of over 20 million and has been classified as a megacity [71-72]. The data used for this study were obtained using questionnaires. The questionnaire used in the survey was designed by the researchers based on the findings from the review of relevant literature. The questionnaire was divided into five main sections: A, B, C, D and $\mathrm{E}$ in line with the subject matter investigated. Section $\mathrm{A}$ deals with the demographic characteristics of the professionals, while section $\mathrm{B}$ and $\mathrm{C}$ had questions on potential causes of climate change and adversarial effects of climate change respectively. 
For section B, the scale of measurement used was the five point Likert type scales of "1" for strongly disagree, " 2 " for disagree, "3" for Undecided, "4" for Agree, "5" for strongly agree while for Section $\mathrm{C}$ the Likert type scale used ranges from 1= no effect, 2= Minor effect, 3= Neutral, 4= moderate effect, to 5= Major effect . In Section D, the awareness of built environment professionals to climate change adaptation and mitigation strategies was measured using a scale of measurement of $1=$ not at all aware, $2=$ slightly aware, $3=$ somewhat aware, $4=$ moderately aware, $5=$ extremely aware. Section $\mathrm{E}$ was then used to measure the level of adoption of climate change adaptation and mitigation strategies. A 5-point Likert scale ranging from " 1 " for never, "2" for rarely, "3" for sometimes, "4" for often, " 5 " for Always was used. The sample size was selected from the population of registered and unregistered built environment professionals using a convenience sampling method. This method was adequate due to the lack of a comprehensive list of built environment professionals in the study area.

Seventy one (71) built environment professionals participated in the study in the fields of architecture, urban and regional planning, building technology, quantity surveying and estate management. The Survey was carried out in March 2018. Online questionnaires were used to obtain the data. The questionnaires were collected, coded and analysed. The data were analysed using simple descriptive statistics. Sum of the weighted values (SWV) over the total value was obtained for each of the variables. Subsequently, ranking was done based on the index. Variables that are ranked from first to last in decreasing order of the weight based on the Likert scale coding. Factors that are ranked first are of top importance while those that are ranked last are of least importance. The results are presented using tables and charts

\section{$\mathrm{Q}=\mathrm{EFx} / \mathrm{N}$}

Where, $\mathrm{Q}=$ Mean, $\Sigma=$ Summation, $\mathrm{Fx}=$ Frequency of $\mathrm{x}$ and $\mathrm{N}=$ Number of occurrences. In order to obtain the perception aggregate index (I) of each service, a weight value of 5,4,3,2 and 1 was assigned to the ratings of the 5-point Likert scale. The summation of weight value (SWV) for each variable was obtained from the addition of the product of weight value of each rating and the number of responses of each rating. The perception aggregate index (I) for each variable was obtained from the division of each summation of value (SWV) by the total number of respondents which is represented as "N".

Index $(\mathrm{I})=\mathrm{Swv} / \mathrm{N}$

\section{RESULTS AND DISCUSSION}

\section{A. Demographic characteristics of the respondents}

The respondents' demographic characteristics are summarised in Table 1. The data in Table 1 reveals that 53 professionals who make up $74.6 \%$ of the participants in the survey are males and 18 professionals who make up to 25.4 $\%$ of the sample are females. This shows that the built environment professionals encountered in the survey are mostly male; suggesting that the built environment profession in the study area is male dominated. Regarding the respondents' age, $77.5 \%$ of the respondents were between the ages of (25-40) years, $7 \%$ were between the ages of (41-50) years and $1.4 \%$ of the respondents were between the ages of
(51-60) years at the time of the survey. This shows that the majority of the respondents are young professionals. On the gender of the respondents, the results revealed that around $64.8 \%$ of the respondents were married while the remaining $35.2 \%$ were single. The working experience of the professionals revealed that $31(67.7 \%)$ had $1-5$ years industry experience, $14(19.7 \%)$ had $6-10$ years of industry experience, $6(8.5 \%)$ had $11-15$ years of industry experience, $2(2.8)$ had $16-20$ years of industry experience and $1(1.4 \%)$ had over 20 years of industry experience. Further, the result revealed that around $49.3 \%$ of the respondents had their professional training in Architecture $36.6 \%$ were trained in Urban and Regional Planning while the remaining 2.8\%, $5.6 \%, 5.6 \%$ have their professional background in Building, Estate Management and Quantity Surveying, respectively. In addition, around $95.8 \%$ of the respondents were trained within Nigeria while the remaining $4.2 \%$ studied abroad with 4 1(57.7\%) having a Master's degree as their highest educational qualification.

From this finding, it can be seen that relatively young, highly educated and experienced professionals dominate the built environment, and thus they are qualified to provide reliable data for the research.

\section{B. Causes of Climate Change}

Result on the potential causes of climate change in study area as perceived by the professional who participated in the survey is presented in Table 2.

From the result in Table 2, it is evident that the professionals encountered in the survey identified activities of industries in different sectors, burning of fossil fuels by oil producing companies and refineries and activities of automobiles as the major causes of climate change. This suggests that activities of industries are the major cause of climate change in developing countries, which collaborates the findings of a previous study by [64]. It is obvious from this that rapid industrialization, fossil fuel burning, heavy dependence on automobiles, felling of trees and indiscriminate bush burning are the major human activities that have contributed to climate change. This result was to be expected because the study area is one of the most densely populated areas in sub-Saharan Africa where a large number of automobile adds to the pollution index as noted by [11] However, the professionals seem not to agree that agricultural activities, religious and superstitious beliefs are the likely causes of climate change in the study areas. This is probably because the study area is not known for extensive agricultural activities and the respondents are well educated and from different religious backgrounds. 
Table- 1: Demographic characteristics of respondents

\begin{tabular}{|c|c|c|c|}
\hline Demographic Characteristics & Input Variables & Frequency & Percentage (\%) \\
\hline \multirow{2}{*}{ Gender } & Male & 53 & 74.6 \\
\hline & Female & 18 & 25.4 \\
\hline \multirow{3}{*}{ Age } & $25-40$ & 55 & 77.5 \\
\hline & $41-50$ & 5 & 7.0 \\
\hline & $51-60$ & 1 & 1.4 \\
\hline \multirow{2}{*}{ Marital status } & Single & 46 & 64.8 \\
\hline & Married & 25 & 35.2 \\
\hline \multirow{4}{*}{ Highest level of Education } & HND (Highest National Diploma) & 3 & 4.2 \\
\hline & B.Sc (Bachelors' degree) & 23 & 32.4 \\
\hline & M.Sc (Masters' degree) & 41 & 57.7 \\
\hline & Ph.D (Doctorate degree) & 4 & 5.6 \\
\hline \multirow{5}{*}{ Professional Background } & Architecture & 35 & 49.3 \\
\hline & Urban and Regional planning & 26 & 36.6 \\
\hline & Building Technology & 2 & 2.8 \\
\hline & Quantity Surveying & 4 & 5.6 \\
\hline & Estate Management & 4 & 5.6 \\
\hline \multirow{2}{*}{ Where did u study? } & Nigeria & 68 & 95.8 \\
\hline & Abroad & 3 & 4.2 \\
\hline \multirow{5}{*}{ Industry Work Experience (in years) } & $1-5$ & 48 & 67.6 \\
\hline & $6-10$ & 14 & 19.7 \\
\hline & $11-15$ & 6 & 8.5 \\
\hline & $16-20$ & 2 & 2.8 \\
\hline & $>20$ & 1 & 1.4 \\
\hline
\end{tabular}

Table- 2: Potential causes of climate change in the world's environment

\begin{tabular}{|c|c|c|c|c|c|c|c|c|}
\hline Causes of climate change & 1 & 2 & 3 & 4 & 5 & SWV & INDEX & RANK \\
\hline Activities of industries in different sectors & $9(12.7 \%)$ & $1(1.4 \%)$ & $1(1.4 \%)$ & $11(15.5 \%)$ & $49(69.0 \%)$ & 303 & 4.27 & $1^{\text {st }}$ \\
\hline $\begin{array}{l}\text { Burning of fossil fuels by oil producing } \\
\text { companies and refineries }\end{array}$ & $9(12.7 \%)$ & $1(1.4 \%)$ & $2(2.8 \%)$ & 13(18.3) & $46(64.8 \%)$ & 299 & 4.21 & $2^{\text {nd }}$ \\
\hline Activities of automobiles & $9(12.7 \%)$ & $1(1.4 \%)$ & $4(5.6 \%)$ & $21(29.6 \%)$ & $36(50.7 \%)$ & 285 & 4.01 & $3^{\text {rd }}$ \\
\hline $\begin{array}{l}\text { Land use change such as deforestation and } \\
\text { desertification }\end{array}$ & $10(14.1 \%)$ & $4(5.6 \%)$ & $5(7.0 \%)$ & $20(28.2 \%)$ & $32(45.1 \%)$ & 273 & 3.84 & $4^{\text {th }}$ \\
\hline Bush burning & $11(15.5 \%)$ & $6(8.1 \%)$ & $4(5.6 \%)$ & $24(33.8 \%)$ & $26(36.6 \%)$ & 261 & 3.68 & $5^{\text {th }}$ \\
\hline Use of charcoal/firewood & $7(9.9)$ & $10(14.1 \%)$ & $10(14.1 \%)$ & $23(32.4 \%)$ & $21(29.6 \%)$ & 254 & 3.57 & $6^{\text {th }}$ \\
\hline Destruction of wetlands & $9(12.7 \%)$ & $7(9.9 \%)$ & $16(22.5 \%)$ & $15(21.1 \%)$ & $24(33.8 \%)$ & 251 & 3.54 & $7^{\text {th }}$ \\
\hline Mining activities & $10(14.1 \%)$ & $8(11.3 \%)$ & $12(16.9 \%)$ & $22(31.0 \%)$ & $19(26.8 \%)$ & 245 & 3.45 & $8^{\text {th }}$ \\
\hline Construction activities & $8(11.3 \%)$ & $15(21.1 \%)$ & $14(19.7 \%)$ & $13(18.3 \%)$ & $21(19.6 \%)$ & 237 & 3.34 & $9^{\text {th }}$ \\
\hline Large scale farming & $12(16.9 \%)$ & $26(36.6 \%)$ & $14(19.7 \%)$ & $10(14.1 \%)$ & $9(12.7 \%)$ & 191 & 2.69 & $11^{\text {th }}$ \\
\hline God's judgement & $34(47.9 \%)$ & $19(26.8 \%)$ & $11(15.5 \%)$ & $3(4.2 \%)$ & $4(5.6)$ & 137 & 1.92 & $12^{\text {th }}$ \\
\hline Activities of the enemies/ spiritual attack & $46(64.8 \%)$ & $13(18.3 \%)$ & $11(15.5 \%)$ & $0(0 \%)$ & $1(1.4 \%)$ & 110 & 1.54 & $13^{\text {th }}$ \\
\hline
\end{tabular}

Table- 3: Adversarial effects of climate change to the world's environment

\begin{tabular}{|c|c|c|c|c|c|c|c|c|}
\hline Effects of climate change & 1 & 2 & 3 & 4 & 5 & SWV & Index & Rank \\
\hline Flooding & $1(1.4 \%)$ & $1(1.4 \%)$ & $0(0.0 \%)$ & $16(22.5 \%)$ & $53(74.6 \%)$ & 330 & 4.64 & $1^{\text {st }}$ \\
\hline Excessive Heat/Higher temperature & $1(1.4 \%)$ & $3(4.2 \%)$ & $1(1.4 \%)$ & $14(19.7 \%)$ & $52(73.2 \%)$ & 326 & 4.59 & $2^{\text {nd }}$ \\
\hline Rising sea/ocean levels & $1(1.4 \%)$ & $2(2.8 \%)$ & $2(2.8 \%)$ & $21(29.6 \%)$ & $45(63.4 \%)$ & 321 & 4.52 & $3^{\text {rd }}$ \\
\hline Longer/Shorter raining season & $1(1.4 \%)$ & $6(8.5 \%)$ & $4(5.6 \%)$ & $24(33.8 \%)$ & $36(50.7 \%)$ & 301 & 4.24 & $4^{\text {th }}$ \\
\hline Increase in storm intensity & $2(2.8 \%)$ & $3(4.2 \%)$ & $12(16.9 \%)$ & $24(33.8 \%)$ & $31(43.7 \%)$ & 295 & 4.15 & $5^{\text {th }}$ \\
\hline Erosion(frequency and intensity) & $3(4.2 \%)$ & $6(8.5 \%)$ & $4(5.6 \%)$ & $24(33.8 \%)$ & $34(47.8 \%)$ & 293 & 4.13 & $6^{\text {th }}$ \\
\hline Desertification & $2(2.8 \%)$ & $3(4.2 \%)$ & $12(16.9 \%)$ & $21(29.6 \%)$ & $33(46.5 \%)$ & 293 & 4.13 & $6^{\text {th }}$ \\
\hline More frequent Drought & $2(2.8 \%)$ & $6(8.5 \%)$ & $5(7.0 \%)$ & $27(38.0 \%)$ & $31(43.7 \%)$ & 292 & 4.11 & $8^{\text {th }}$ \\
\hline Well, stream and river drying up & $3(4.2 \%)$ & $4(5.6 \%)$ & $10(14.1 \%)$ & 23(32.4) & $31(43.7)$ & 288 & 4.06 & $9^{\text {th }}$ \\
\hline Proliferation of pests and diseases & $6(8.5 \%)$ & $1(1.4 \%)$ & $19(26.8 \%)$ & $22(31.0 \%)$ & $23(32.4 \%)$ & 268 & 3.77 & $10^{\text {th }}$ \\
\hline
\end{tabular}

Published By: 


\begin{tabular}{|c|c|c|c|c|c|c|c|c|}
\hline Landslide & $4(5.6 \%)$ & $9(12.7 \%)$ & $16(22.5 \%)$ & $19(26.8 \%)$ & $23(32.4 \%)$ & 261 & 3.68 & $11^{\text {th }}$ \\
\hline Crop yield reduction and food scarcity & $6(8.5 \%)$ & $5(7.0 \%)$ & $12(16.9 \%)$ & $25(35.2 \%)$ & $23(32.4 \%)$ & 234 & 3.30 & $12^{\text {th }}$ \\
\hline
\end{tabular}

1= no effect, 2= Minor effect, 3= Neutral, 4= moderate effect, to 5= Major effect .

Table- 4: Level of awareness on climate change adaptation and mitigation strategies

\begin{tabular}{|c|c|c|c|c|c|c|c|c|}
\hline $\begin{array}{l}\text { Adaptation strategies to climate } \\
\text { change }\end{array}$ & 1 & 2 & 3 & 4 & 5 & SWA & Index & Rank \\
\hline Greenery/Planting trees & $1(1.4 \%)$ & $3(4.2 \%)$ & $4(5.6 \%)$ & $12(16.9 \%)$ & $51(71.8 \%)$ & 322 & 4.54 & $1^{\text {st }}$ \\
\hline Enforcement of building guidelines & $3(4.2 \%)$ & $1(1.4 \%)$ & $11(15.5 \%)$ & $17(24.0 \%)$ & $39(54.9 \%)$ & 301 & 4.24 & $2^{\text {nd }}$ \\
\hline Use of energy-efficient technologies & $3(4.2 \%)$ & $4(5.6 \%)$ & $9(12.7 \%)$ & $14(19.7 \%)$ & $41(57.7 \%)$ & 299 & 4.21 & $3^{\text {rd }}$ \\
\hline Public awareness on climate & $1(1.4 \%)$ & $5(7.0 \%)$ & $10(14.1 \%)$ & $18(25.4 \%)$ & $37(52.1 \%)$ & 298 & 4.20 & $4^{\text {th }}$ \\
\hline $\begin{array}{l}\text { Demolishing structures obstructing } \\
\text { drainage }\end{array}$ & $5(7.0 \%)$ & $2(2.8 \%)$ & $7(9.9 \%)$ & $17(23.9 \%)$ & $40(56.3 \%)$ & 298 & 4.20 & $4^{\text {th }}$ \\
\hline $\begin{array}{l}\text { Avoiding development on flood } \\
\text { prone lands }\end{array}$ & $4(5.6 \%)$ & $2(2.8 \%)$ & $11(15.5 \%)$ & $13(18.3 \%)$ & $41(57.7 \%)$ & 298 & 4.20 & $4^{\text {th }}$ \\
\hline Use of resilient building materials & $2(2.8 \%)$ & $5(7.0 \%)$ & $8(11.3 \%)$ & $19(26.8 \%)$ & $37(52.1 \%)$ & 297 & 4.18 & $7^{\text {th }}$ \\
\hline $\begin{array}{l}\text { Compliance with setbacks during } \\
\text { property development }\end{array}$ & $4(5.6 \%)$ & $4(5.6 \%)$ & $9(12.7 \%)$ & $15(21.1 \%)$ & $39(55.0 \%)$ & 294 & 4.14 & $8^{\text {th }}$ \\
\hline advancement of renewable energy & $4(5.6 \%)$ & $5(7.0 \%)$ & $9(12.7 \%)$ & 17(23.9\%) & $36(50.7 \%)$ & 289 & 4.07 & $9^{\text {th }}$ \\
\hline $\begin{array}{l}\text { Building of dams for flood } \\
\text { protection }\end{array}$ & 6(8.5\%) & $3(4.2 \%)$ & $11(15.5 \%)$ & 14(19.7\%) & $37(52.1 \%)$ & 286 & 4.03 & $10^{\text {th }}$ \\
\hline $\begin{array}{l}\text { Construction of a sea wall to protect } \\
\text { low-lying coastal areas from rising } \\
\text { sea levels }\end{array}$ & $7(9.9 \%)$ & $6(8.5 \%)$ & $8(11.3 \%)$ & $16(22.5 \%)$ & $34(47.9 \%)$ & 277 & 3.90 & $11^{\text {th }}$ \\
\hline $\begin{array}{l}\text { Construction of drainage channels } \\
\text { around houses }\end{array}$ & $6(8.5 \%)$ & $7(9.9 \%)$ & 8(11.3\%) & 21(29.6) & $29(40.8 \%)$ & 273 & 3.85 & $12^{\text {th }}$ \\
\hline $\begin{array}{l}\text { Restriction of land reclamation } \\
\text { activities }\end{array}$ & $5(7.0 \%)$ & $5(7.0 \%)$ & 14(19.7\%) & $20(28.2 \%)$ & $27(38.0 \%)$ & 272 & 3.83 & $13^{\text {th }}$ \\
\hline Producing and using flood risk maps & $12(16.9 \%)$ & $5(7.0 \%)$ & $9(12.7 \%)$ & $20(28.2 \%)$ & $25(35.2 \%)$ & 254 & 3.58 & $14^{\text {th }}$ \\
\hline Raising the building level & $12(16.9 \%)$ & $5(7.0 \%)$ & $7(9.9 \%)$ & $19(28.2 \%)$ & 28(39.4) & 259 & 3.65 & $15^{\text {th }}$ \\
\hline Reliance on weather forecast & $9(12.7 \%)$ & $8(11.3 \%)$ & $15(21.1 \%)$ & $23(32.4)$ & $16(22.5 \%)$ & 242 & 3.40 & $16^{\text {th }}$ \\
\hline $\begin{array}{l}\text { Building high walls to prevent } \\
\text { floods }\end{array}$ & $12(16.9 \%)$ & $9(12.7 \%)$ & $12(16.9 \%)$ & $18(25 \%)$ & $20(28.2 \%)$ & 238 & 3.35 & $17^{\text {th }}$ \\
\hline Repair/Replace damaged property & $15(21.1 \%)$ & $9(12.7 \%)$ & $10(14.1 \%)$ & $22(31.0 \%)$ & $15(21.1 \%)$ & 226 & 3.18 & $18^{\text {th }}$ \\
\hline $\begin{array}{l}\text { Use of local herbs and drugs to } \\
\text { climate related diseases }\end{array}$ & $33(46.5 \%)$ & $9(12.7 \%)$ & $9(12.7 \%)$ & $11(15.5 \%)$ & $9(12.7 \%)$ & 167 & 2.35 & $19^{\text {th }}$ \\
\hline Consulting the rainmaker & $44(62.0 \%)$ & $12(16.9 \%)$ & $8(11.3 \%)$ & $4(5.6 \%)$ & $3(4.2 \%)$ & 123 & 1.73 & $20^{\text {th }}$ \\
\hline Use of prayers/charms/incantations & $44(62.0 \%)$ & $8(11.3 \%)$ & $7(9.9 \%)$ & $6(8.5 \%)$ & $6(8.5 \%)$ & 135 & 1.90 & $21^{\mathrm{st}}$ \\
\hline
\end{tabular}

1= not at all aware, 2= slightly aware, 3= somewhat aware, 4= moderately aware, 5= extremely aware

Table- 5: Extent of using climate change adaptation and mitigation strategies

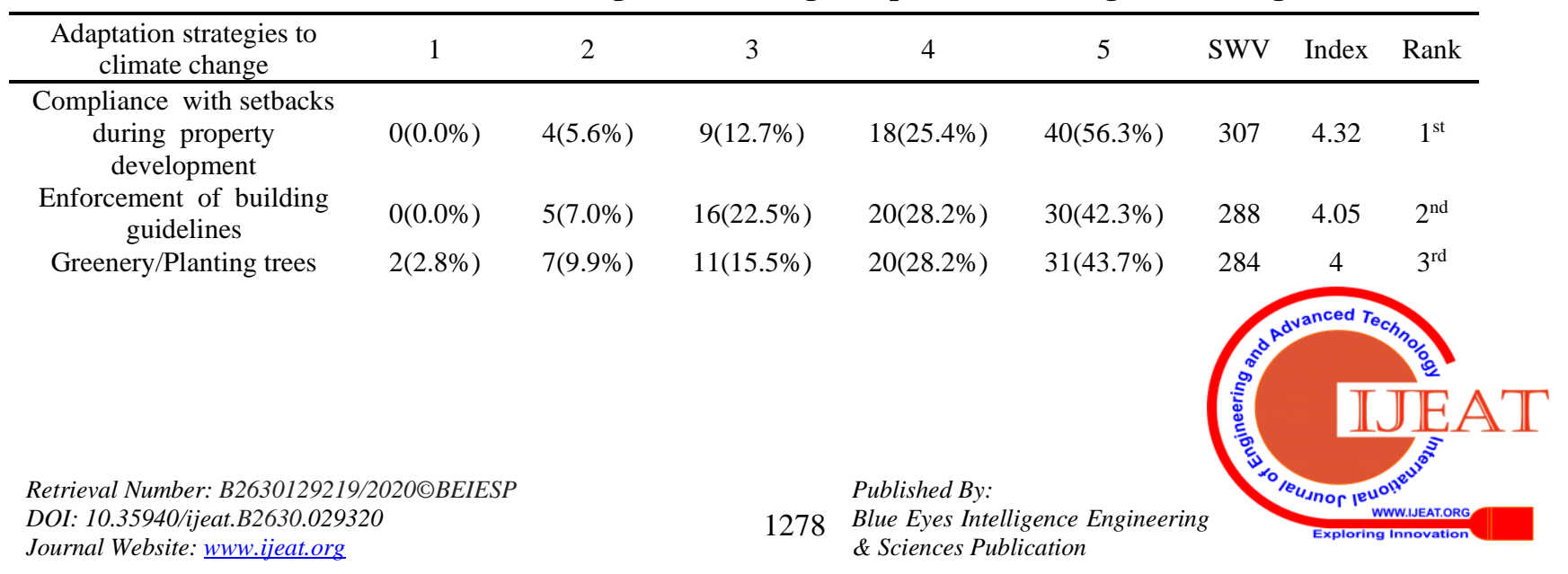




\begin{tabular}{|c|c|c|c|c|c|c|c|c|}
\hline $\begin{array}{l}\text { Avoiding development on } \\
\text { flood prone lands }\end{array}$ & $4(5.6 \%)$ & $5(7.0 \%)$ & $12(16.9 \%)$ & 23(32.3\%) & $27(38.0 \%)$ & 277 & 3.9 & $4^{\text {th }}$ \\
\hline Public awareness on climate & $2(2.8 \%)$ & $8(11.3 \%)$ & 13(18.3\%) & $21(29.6 \%)$ & $27(38.0 \%)$ & 276 & 3.89 & $5^{\text {th }}$ \\
\hline $\begin{array}{l}\text { Use of energy-efficient } \\
\text { technologies }\end{array}$ & $4(5.6 \%)$ & 7(9.9\%) & 12(16.9\%) & $20(28.2 \%)$ & 28(39.4\%) & 274 & 3.86 & $6^{\text {th }}$ \\
\hline $\begin{array}{l}\text { Use of resilient building } \\
\text { materials }\end{array}$ & $4(5.6 \%)$ & $8(11.3 \%)$ & 13(18.3\%) & $20(28.2 \%)$ & $26(36.6 \%)$ & 269 & 3.78 & $7^{\text {th }}$ \\
\hline $\begin{array}{l}\text { Demolishing structures } \\
\text { obstructing drainage }\end{array}$ & 7(9.9\%) & $5(7.0 \%)$ & $14(19.7 \%)$ & $17(23.9 \%)$ & $28(39.4 \%)$ & 267 & 3.76 & $8^{\text {th }}$ \\
\hline Raising the building level & $4(5.6 \%)$ & 9 & $11(15.5 \%)$ & $23(32.4 \%)$ & $24(33.8 \%)$ & 267 & 3.76 & $9^{\text {th }}$ \\
\hline $\begin{array}{l}\text { Construction of drainage } \\
\text { channels around houses }\end{array}$ & $7(9.9 \%)$ & $8(11.3 \%)$ & 14(19.7\%) & $17(23.9 \%)$ & $25(35.2 \%)$ & 258 & 3.63 & $10^{\text {th }}$ \\
\hline $\begin{array}{l}\text { advancement of renewable } \\
\text { energy }\end{array}$ & $8(11.3 \%)$ & $12(16.9 \%)$ & 13(18.3\%) & $15(21.1 \%)$ & $23(32 \%)$ & 246 & 3.46 & $11^{\text {th }}$ \\
\hline $\begin{array}{l}\text { Restriction of land } \\
\text { reclamation activities }\end{array}$ & $11(15.5 \%)$ & $7(9.9 \%)$ & 14(19.7\%) & $20(28.2 \%)$ & $19(26.8 \%)$ & 242 & 3.4 & $12^{\text {th }}$ \\
\hline $\begin{array}{l}\text { Reliance on weather } \\
\text { forecast }\end{array}$ & $9(12.7 \%)$ & $10(14.1 \%)$ & $17(23.9 \%)$ & $19(26.8 \%)$ & $16(22.5 \%)$ & 236 & 3.32 & $13^{\text {th }}$ \\
\hline $\begin{array}{l}\text { Construction of a sea wall } \\
\text { to protect low-lying coastal } \\
\text { areas from rising sea levels }\end{array}$ & $15(21.1 \%)$ & $9(12.7 \%)$ & $11(15.5 \%)$ & 17(23.9\%) & $19(26.8 \%)$ & 229 & 3.23 & $14^{\text {th }}$ \\
\hline $\begin{array}{l}\text { Building of dams for flood } \\
\text { protection }\end{array}$ & $15(21.1 \%)$ & 11(15.5\%) & 11(15.5\%) & 17(23.9\%) & 17(23.9\%) & 223 & 3.14 & $15^{\text {th }}$ \\
\hline $\begin{array}{l}\text { Building high walls to } \\
\text { prevent floods }\end{array}$ & 15(21.1\%) & $12(16.9 \%)$ & $9(12.7 \%)$ & $20(28.2 \%)$ & 15(21.1\%) & 221 & 3.11 & $16^{\text {th }}$ \\
\hline $\begin{array}{l}\text { Producing and using flood } \\
\text { risk maps }\end{array}$ & 14(19.7\%) & 13(18.3\%) & 13(18.3\%) & 17(23.9\%) & 14(19.7\%) & 217 & 3.05 & $17^{\text {th }}$ \\
\hline $\begin{array}{l}\text { Repair/Replace damaged } \\
\text { property }\end{array}$ & $18(25.4 \%)$ & 11(15.5\%) & 13(18.3\%) & 11(15.5\%) & $18(25.4 \%)$ & 213 & 3 & $18^{\text {th }}$ \\
\hline $\begin{array}{c}\text { Use of } \\
\text { prayers/charms/incantations }\end{array}$ & $50(70.4 \%)$ & 8(11.3\%) & $4(5.6 \%)$ & 8(11.3\%) & $1(1.4 \%)$ & 115 & 1.62 & $19^{\text {th }}$ \\
\hline $\begin{array}{l}\text { Consulting the rainmaker } \\
\text { Use of local herbs and }\end{array}$ & $52(73.2 \%)$ & $9(12.7 \%)$ & $1(1.4 \%)$ & $6(8.5 \%)$ & $3(4.2 \%)$ & 112 & 1.58 & $20^{\text {th }}$ \\
\hline $\begin{array}{c}\text { drugs to climate related } \\
\text { diseases }\end{array}$ & $39(54.9 \%)$ & $10(14.1 \%)$ & $8(11.3 \%)$ & $9(12.7 \%)$ & $5(7.0 \%)$ & 144 & 2.03 & $21^{\text {th }}$ \\
\hline
\end{tabular}

\section{Causes of Climate Change}

Regarding the adverse effects of climate change, the result is as presented in Table 3 . The result (Table 3 ) shows that flooding was identified as the major consequence of climate change followed by excessive heat/high temperature. It can be established from this study that the prevailing problem related to climate change effect in the built environment is flooding.

This finding on the adverse effects of climate change in the study area appears to agree with the findings by [63] who found that flooding was a major environmental disaster militating against the growth and development of Lagos and that the poor in coastal areas are the most vulnerable to flooding risk. The study by [19] revealed that flooding and excessive heat waves were mostly the perceived adverse effects of climate change while landslide and crop yield reduction are the least. This is not unconnected with the topography of the study area which makes it vulnerable to flood. Previous studies [67] have shown that low-lying lands are most vulnerable to floods. The situation in Lagos has been compounded because the canals built to regulate flooding are often blocked with the erection of illegal building structures and solid waste [15]. This goes to suggest that poor solid waste management practices in Lagos are contributing to exacerbating the incidence of flood and its concomitant effects on human and ecological system in Lagos.

\section{Level of awareness of climate change adaptation and mitigation strategies}

The result on the level of awareness of climate change adaptation and mitigation strategies are presented in Table 4. It is evident from Table 4 that planting trees/greenery, enforcement of building guidelines, the use of energy efficient technologies, public awareness are the adaptation and mitigation strategies that the respondents were highly aware of, while the respondents were least aware of consulting the rainmaker and, the use of charms and incantations. Interestingly, this finding is consistent with the finding of previous author [63] indicating the installation of green infrastructural facilities such as green areas, recreational parks, urban forestry and enforcement of building regulations as well as the use of energy efficient technologies are some of the key climate change adaptation and mitigation strategies in developing countries. The result is also in line with the findings of previous authors [18] [19] who also identified the planting of bio-indicators and tolerant tree species and energy efficient considerations in architectural design of buildings and the surrounding environment as critical climate change adaptation and mitigation strategies. Emetere [19] made it clear that tree planting will ensure the greening of the environment thereby reducing the effect of climate change and incorporation of energy efficient technologies in the built environment will ensure sustainable development of the sector. 
Further, enforcement of building guidelines [5] and the use of energy efficient technologies [16] [73] have been identified are the most reliable adaptation and mitigation strategies to climate change. The study, however, contradicts the findings by [65] suggesting that the use of charms and incarnation was a very popular climate change adaptation strategy in the study area. From the result in Table 4, it can be inferred that the built environment professionals encountered in the survey are very much aware of the various climate change adaptation and mitigation strategies.

\section{E. Extent of adoption of identified climate change adaptation and mitigation strategies}

The study also investigated which aspects of the climate change adaptation and mitigation strategies the built environment professionals have implemented in the study area. The result is as presented in Table 5 .

It can be seen in Table 5 that the top three climate change adaptation and mitigation strategies implemented by the professionals are: "compliance with building setbacks", "enforcement of building guidelines " and "planting trees/ greenery", while the least is the use of prayers, rainmakers and local herbs and drugs for climate change related illnesses and diseases. These findings are in agreement with [63] as perceived by residents in Lagos and consistent with the previous research findings [15] [65] on the available strategies to combat the different effects of climate change. This suggests that both the residents and built environment professionals in the study area share similar views on climate change adaption and mitigation strategies in Lagos. This has not come as a surprise because many of the built environment professionals who participated in the survey work and live within and around Lagos and its environs. Further, in support of previous studies [23-24] [26], this study has shown there seem to be consistency on the climate adaptation and mitigation strategies the professionals are aware and the ones they have implemented because the top three strategies implemented are also the ones they are aware of. It can, therefore, be inferred from this study that there is a direct relationship between awareness of climate adaptation and mitigation strategies and their adoption among built environment professionals in the study area.

\section{CONCLUSION}

This study investigated climate change adaptation and mitigation strategies from the perspectives of built environment professionals in Lagos, Nigeria. From the findings, the following conclusions are made. The first conclusion is that the main cause of climate change in the study area is greenhouse gases (GHGs) emission from industries, the use of fossil fuels for electricity generation and in automobiles. The second conclusion is that the principal consequences of climate change in the study area are flooding and excessive heat/high temperature rise. The last conclusion is that planting trees/greenery, enforcement of building guidelines, the use of energy efficient technologies are the top climate change adaptation and mitigation strategies the built environment professionals in Lagos, Nigeria are aware of and have implemented in the study area.

Findings of this study imply that the built environment professionals in the study area are very much aware of the causes, consequences and adaptation and mitigation strategies for the effects of climate change. However, the study suggests that many of the strategies were yet to benefit from a critical mass adoption by the professionals. It is suggested that while the current strategies such as compliance with building setbacks, enforcement of building guidelines, installation of green infrastructure and the use of energy efficient technologies and others should be sustained. Further studies are needed to unearth the reason behind the relatively low adoption of other strategies identified in this study and what steps that needs to be taken to address this situation. In addition, it is suggested that among the residents, there is a need for attitudinal change, especially in the use of fossil fuel for electricity generation and heavy dependence of automobile use. There is also a need to strictly enforce the existing penalty on industries that contribute to the level of GHGs emissions in the country to serve as deterrents to future offenders.

The findings of this study are limited to the bias and views of selected built environment professionals in the study area, and thus may not be generalized for other professionals in the study areas who also have an interest in the issues of climate change. Therefore, future studies might consider the views of other stakeholders in the study area. The study is also limited to a questionnaire survey and on some variables identified from the review of literature. Other studies should consider the inclusion of more variables and adopt mixed methods of data collection for a different result.

\section{ACKNOWLEDGEMENT}

Covenant University is acknowledged for the sponsorship of this research.

\section{REFERENCES}

1. Akinola, A. O., Salau, T., Oluwatayo, A., Babalola, O. \& Okagbue, H. I. (2018). Data on the awareness and adoption of ICT in town planning firms in Lagos state, Nigeria. Data in Brief, 20, 436-447

2. Ajibade, I., \& McBean, G. (2014). Climate extremes and housing rights: A political ecology of impacts, early warning and adaptation constraints in Lagos slum communities. Geoforum, 55, 76-86.

3. Ibem, E. O., Ayo-Vaughan, E. A., Oluwunmi, A. O. \& Alagbe, O. A. (2019). Residential Satisfaction among Low-Income Earners in Government-Subsidized Housing Estates in Ogun State, Nigeria. Urban Forum, 30(1), 75-96.

4. Ajakaiye, O.O., Afolabi, H. A., Akinola, A. O., Okagbue, H. I., Olagunju, O. O. \& Adetoro, O. O. (2018).Datasets on factors influencing trading on pedestrian bridges along Ikorodu road, Lagos, Nigeria. Data in Brief, 19, 1584-1593.

5. Ibem, E. O., Akinola, A. O., Erebor, E. M., Tolani, M. O. \& Nwa-uwa A. E. (2018). Survey data on digitalization of building procurement process by architectural firms in Abuja, Nigeria. Data in Brief, 20, 1062-1067.

6. Babalola, O., Ibem, E. O. \& Ezema, I. C. (2019). Implementation of lean practices in the construction industry: A systematic review. Building and Environment, 148, 34-43.

7. Adewale, B. A., Ibem, E. O., Amole, B. \& Adeboye, A. B. (2019) Assessment of residential satisfaction in the core area of Ibadan Metropolis, Nigeria. Journal of Human Behaviour and Social Environment, 29(2), 206-233.

8. Erebor, E., Ibem, E. O. \& Adewale, B. A. (2019). Current research trends on sustainable construction project delivery. International Journal of Mechanical Engineering and Technology, 10(1), 1973-1986.

9. Sulaiman, A. L. \& Taleb, H. (2018). Climate responsive container design for sustainable dwellings. Lect. Notes Civil Engine, 6, 397-412. 
10. Ojo, O., Gbuyiro, S. O. \& Okoloye, C. U. (2004). Implications of climatic variability and climate change for water resources availability and management in West Africa. GeoJournal, 61(2), 111-119.

11. Babajide, S. O. \& Aderemi, M. O. (2011). Water and disaster management in Nigeria: The real estate sector perspective. WIT Transaction on Ecology and Environment, 153, 539-550.

12. Igwe, O. \& Fukuoka, H. (2013). Landslides in West Africa: Impact, mechanisms and management. Landslides: Global Risk Preparedness, pp. 351-367.

13. Adewole, I. F., Agbola, S. B. \& Kasim, O. F. (2015). Building resilience to climate change impacts after the 2011 flood disaster at the University of Ibadan, Nigeria. Environ. Urbanisation, 27(1), 199-216.

14. Adetokunbo, I. \& Emeka, M. (2015). Urbanization, housing, homelessness and climate change adaptation in Lagos, Nigeria: Lessons from Asia. Journal Design Built Environment, 15(2), 15-28.

15. Lienou, G., Mahe, G., Piih, S. L., Sighomnou, D., Paturel, J. E. \& Bamba, F. (2014). Is the building of dams an adaptation strategy to fight against drought in the basin of the River Niger? IAHS-AISH Proceedings and Reports, 363, 197-202.

16. Adebamowo, M. \& Olusanya, O. (2012). Energy savings in housing through enlightened occupant behaviour and by breaking barriers to comfort: - A case study of a hostel design in Nigeria. Proceedings of 7th Windsor Conference: The Changing Context of Comfort in an Unpredictable World.

17. Ebhuoma, E. \& Simatele, D. (2017). Defying the odds: Climate variability, asset adaptation and food security nexus in the Delta State of Nigeria. Int. J.. Disaster Risk Reduction, 21, 231-242.

18. Anake, W. U., Bayode, F. O., Omonhinmin, C. A. \& Williams, A. B (2018). Ambient air pollution control using air pollution tolerance index and anticipated performance index of trees. International Journal of Civil Engineering and Technology, 9(12), 417-425.

19. Emetere, M.E. (2019). A modified approach to estimating thermodynamic impact on buildings: A case study of poor urban setting in Lagos state. Journal of. Engineering. Design Technology. 17(1), 115-135.

20. Biesta, G., \& Osberg, D. (2007). Beyond representation: A case for updating the epistemology of schooling. Interchange, 38, 15-29.

21. Hinkel, J. (2011). Indicators of vulnerability and adaptive capacity": Towards a clarification of the science-policy interface. Global Environmental Change, 21(1), 198-208.

22. Amer, N. (2019). Biomimetic Approach in Architectural Education: Case study of 'Biomimicry in Architecture' Course. Ain Shams Engineering Journal, DOI: 10.1016/j.asej.2018.11.005

23. Sumangala, H. P. (2013). Urban landscapes for carbon sequestration in climate changing scenario. Climate-Resilient Horticulture: Adaptation and Mitigation Strategies, 245-253.

24. Bortolini, L., Semenzato, P., Almási, B., Csizmadia, D., Kowalski, P., Racoń-Leja, K., Aarrevaara, E. \& Scherzer, C. (2018) Multidisciplinary approaches for programming ecosystem services of urban green spaces. Acta Horticulturae, 1215, 411-414.

25. Gies, E. (2008). Green building goes mainstream. World Watch, 21(4), 12-19.

26. Yedla, S. \& Park, H. S. (2009). Co-benefit as an approach to align climate change concerns with national development objectives: Solid waste management. J. Material Cycles Waste Magt., 11(2), 123-129.

27. Lapisa, R., Karudin, A., Rizal, F., Krismadinataa \& Nasruddinb (2019). Passive cooling strategies in roof design to improve the residential building thermal performance in tropical region. Asian Journal of Civil Engineering, 20(4), 571-580.

28. Taneja, O. (2011). Measures for maintaining low energy use in commercial buildings over their life-cycle. ASHRAE Transactions, 117(PART 1), 525-532.

29. Arif Kamal, M. (2013). An assessment of climatic design strategy for low energy residential buildings in hot and arid climate. Asian Journal of Civil Engineering, 14(5), 747-754.

30. Mambo, A.D., Efthekhari, M. (2012). Supervisory control of indoor environment systems to minimise the carbon footprint of airport terminal buildings - A review. Smart Innovation, Systems and Technologies, 12, 413-424.

31. Kaveh, A. \& Ardalani, S. (2016). Cost and CO2 emission optimization of reinforced concrete frames using enhanced colliding bodies algorithm. Asian Journal of Civil Engineering, 17(6), 831-858.

32. Mouffok, M., Zemmouri, N., Aidaoui, L., Lasbet, Y. \& De Herde, A. (2017). Effects of building morphologies on CO2 air pollution case study: The vernacular urban fabric, city of Ghardaïa (Algeria). Asian Journal of Civil Engineering, 18(1), 1-19.

33. Sengupta, N., Roy, S. \& Guha, H. (2018). Assessing embodied GHG emission reduction potential of cost-effective technologies for construction of residential buildings of Economically Weaker Section in India. Asian Journal of Civil Engineering, 19(2), 139-156.
34. Veiseh, S. \& Sefidgar, M. (2012). Prediction of effective thermal conductivity of moistened insulation materials by neural network. Asian Journal of Civil Engineering, 13(3), 319-330.

35. Maleki, A. \& Mahdavi, A. (2016). Evaluation of Urban Heat Islands mitigation strategies using 3dimentional urban micro-climate model envi-met. Asian Journal of Civil Engineering, 17(3), 357-371.

36. Nourmohammadzad, H., Alizadeh, H. \& Kheirabadi, F. (2017) Improving climatic comfort emphasizing the effect of sunshine radiation on the proper orientation of the physic of squares in Yazd. Asian Journal of Civil Engineering, 18(1), 99-118.

37. Bhikshma, V., Reddy, M. K. \& Rao, T. S. (2012). An experimental investigation on properties of geopolymer concrete (no cement concrete). Asian Journal of Civil Engineering, 13(6), 841-853.

38. Vijai, K., Kumutha, R. \& Vishnuram, B. G. (2012). Properties of glass fibre reinforced geopolymer concrete composites. Asian Journal of Civil Engineering, 13(4), 511-520.

39. Palazzo, E. \& Wan Mohd Rani, W. N. M. (2017). Regenerating urban areas through climate sensitive urban design. Advanced Science Letters, 23(7), 6394-6398.

40. Assali, I. M. (2017). The contribution of interior design studio in promoting sustainable design in Bahrain. International Journal of Mechanical Engineering and Technology, 8(10), 25-34.

41. Nikravan Mofrad, M. (2014). The impact of floor-to-ceiling height on human comfort. Asian Journal of Civil Engineering, 15(2), 277-288.

42. Tasdemir, C. \& Gazo, R. (2018). A systematic literature review for better understanding of lean driven sustainability. Sustainability, 10(7), Article number 2544.

43. Diga, K., Ngcoya, M., Bracking, S., Lombo, M. \& Ntombela, S (2016). Poverty Reduction Co-benefits through Indigenous Knowledge in Climate Change Adaptation: A Study within the eThekwini Municipality. Journal of Social Sciences, 46(2), 87-97.

44. Boezeman, D. \& de Vries, T. (2019). Climate proofing social housing in the Netherlands: toward mainstreaming? Journal of Environmental Planning and Management, 10.1080/09640568.2018.1510768.

45. Mooij, W. M., Trolle, D., Jeppesen, E.,, Arhonditsis, G., Belolipetsky, P. V., Chitamwebwa, D. B. R., Degermendzhy, A. G., DeAngelis, D. L., De Senerpont Domis, L. N., Downing, A. S., Elliott, J. A., Fragoso Jr., C. R., Gaedke, U., Genova, S. N., Gulati, R. D., Håkanson, L., Hamilton, D. P., Hipsey, M. R., 't Hoen, J., Hülsmann, S., Los, F. H., Makler-Pick, V., Petzoldt, T., Prokopkin, I. G., Rinke, K., Schep, S. A., Tominaga, K., van Dam, A. A., van Nes, E. H., Wells, S. A. \& Janse, J. H. (2010). Challenges and opportunities for integrating lake ecosystem modelling approaches. Aquatic Ecology, 44(3), 633-667.

46. Boyd, A., Hokanson, J. B., Johnson, L. A., Schwab, J. C. \& Topping, K. C. (2014). Planning for post-disaster recovery: Next generation. APA Planning Advisory Service Reports, 576, 1-197

47. Beltran, M. J. (2011). How can the risks associated with climate change help shape Lord Howe Island fire management planning. WIT Transactions on the Built Environment, 119, 137-148.

48. Schmidt, D. H. \& Garland, K. A. (2012). Bone Dry in Texas: Resilience to Drought on the Upper Texas Gulf Coast. Journal of Planning Literature, 27(4), 434-445.

49. Johannessen, Å. \& Wamsler, C. (2017). What does resilience mean for urban water services? Ecology and Society, 22(1), Article no: 1.

50. Knieling, J. \& Fellmer, M. (2013). Climate Adaptation in Metropolis Hamburg: Paradigm Shift in Urban Planning and Water Management towards 'Living with Water'? Climate Change Adaptation in Practice: From strategy development to implementation, pp. 83-93.

51. Weinstein, L., Rumbach, A. \& Sinha, S. (2019). Resilient Growth: Fantasy Plans and Unplanned Developments in India's Flood-Prone Coastal Cities. Int. J. Urban and Regional Research, 43(2), 273-291

52. Ghimire, J., Vu, K. C. \& Thuy, H. N. T. (2018). Resilience Concepts and Planning Realities: How Quy Nhon Is Becoming a Resilient City by Integrating Climate Change Adaptation into Master Plans? Lecture Notes in Energy, 65, 129-146.

53. Yen, Y. N., Cheng, C. F. \& Cheng, H. M. (2015). Disaster risk management and measurement indicators for cultural heritage in Taiwan. ISPRS Annals of the Photogrammetry, Remote Sensing and Spatial Information Sciences, 2(5W3), 383-388.

54. Korhonen-Kurki, K., Brockhaus, M., Bushley, B., Babon, A., Gebara, M. F., Kengoum, F., Pham, T. T., Rantala, S., Moeliono, M. Dwisatrio, B. \& Maharani, C. (2016). Coordination and cross-sectoral integration in REDD+: experiences from seven countries. Climate and Development, 8(5), 458-471. 
55. Davies, H. J., Doick, K. J., Hudson, M. D. \& Schreckenberg, K. (2017). Challenges for tree officers to enhance the provision of regulating ecosystem services from urban forests. Environ. Res., 156, 97-107.

56. Tilbury, D. (1995). Environmental education for sustainability: Defining the new focus of environmental education in the 1990's. Environmental Education Research, 1 (2), 195-212.

57. Allu, E. L. A \& Ekele, T. O. (2015). Sustainable Urban Built Environment for Nigeria: A Framework Approach. International Journal of Contemporary Applied Science, 2(5), 96-107.

58. Alavipanah, S., Haase, D., Lakes, T. \& Qureshi, S. (2017). Integrating the third dimension into the concept of urban ecosystem services: A review. Ecological Indicators, 72, 374-398.

59. Ekins, P. \& Lees, E. (2008). The impact of EU policies on energy use in and the evolution of the UK built environment. Energy policy, 36, 12, 4580-4583.

60. Hossein, Z., Farah, H. \& Leila, M. (2012). Sustainability in building construction: Revising definitions and concepts. International Journal of Emergency Sciences, 2(4), 570-578.

61. Wentz (2015) Assessing the Impacts of Climate Change on the Built Environment under NEPA and State EIA Laws: A Survey of Current Practices and Recommendations for Model Protocols

62. IPCC, Intergovernmental Panel on Climate Change. (2007). Climate Change 2007: The Physical Science

63. Adenekan, I. (2010). Vulnerability of poor urban coastal communities to climate change in Lagos, Nigeria. Environment and Urbanization 22(2), 433-450

64. Odjugo, P. A. O. (2010). Regional Evidence of Climate Change in Nigeria. Journal of Geography and Regional Planning, 3(6), 142-150.

65. Afon, A. O., Dada, O. T. \& Faniran, G. B (2016). Socio-economic attributes of residents as drivers of adaptation to climate change effects in a Nigerian Traditional Urban Centre. Archives of Current Research International, 3(3), 2454-2477.

66. Bello, W. A. Adekunle, R. A. \& Ogunsanmi, O. E. (2012). Effect of Climate Change on Construction Project Planning in Nigeria In: Laryea, S. Agyepong, S.A. Leiringer, R. and Hughes, W. (Eds) Procs 4th West Africa Built Environment Research (WABER) Conference, 24-26 July 2012, Abuja, Nigeria, pp. 399-411.

67. Small, C. \& Nicholls, R. J. (2003). A global analysis of human settlement in coastal zones. J. Coastal Research, 19 (3), 584-599.

68. Dow, K. \& Downing, T. (2006). The Atlas of climate change, Earthscan, London.

69. UN-Habitat (2009) sustainable Urbanisation: Revisiting the role of Urban planning, Global Report on Human Settlements, Nairobi: UN Habitat.

70. Odjugo, P. A. O. (2009). Quantifying the Cost of Climate Change Impact in Nigeria: Emphasis on Wind and Rainstorms. Journal of Human Ecology, 28(2) 93-101.

71. Afolabi , A. O., Ojelabi, R. A., Bukola A., Akinola, A. \& Afolabi, A. (2018). Statistical exploration of dataset examining key indicators influencing housing and urban infrastructure investments in megacities. Data in Brief, 18, 1725-1733.

72. Dekolo, S. O. \& Oduwaye A. O. (2011). Managing the Lagos megacity and its geospatial imperative. International Archives of the Photogrammetric, Remote Sensing and Spatial. Info. Sci., 38 (4), 121-128.

73. Akinola, A. O., Adeboye, A. B, Oluwatayo, A, Alagbe, O. A. \& Babalola, O. (2018). Survey dataset on architect's awareness and adoption of building envelope technologies for energy efficient housing in Lagos State. Data in Brief, 19, 1894-1901

\section{AUTHORS PROFILE}

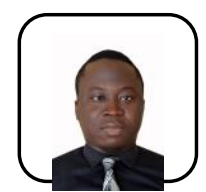

Adedotun O. Akinola, is of the Department of Architecture, Covenant University, Ota, Nigeria.

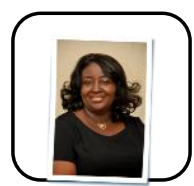

Akunnaya P. Opoko, (Ph.D) is of the Department of Architecture, Covenant University, Ota, Nigeria.

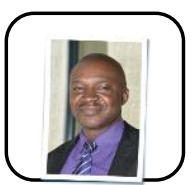

Eziyi O. Ibem (Ph.D) is of the Department of Architecture, Covenant University, Ota, Nigeria.

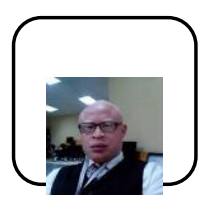

Hilary I. Okagbue (Ph.D) is of the Department of Mathematics, Covenant University, Ota, Nigeria.

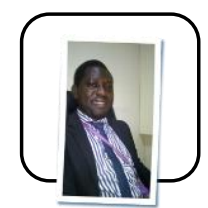

Adedeji O. Afolabi (Ph.D) is of the Department of Building Technology, Covenant University, Ota, Nigeria. 